\title{
Pengembangan Bahan Ajar Berbasis Strategi Think, Predict, Read, Connect untuk Meningkatkan Keterampilan Membaca Pemahaman Siswa Sekolah Dasar
}

\author{
Diah Permata Sari ${ }^{1}$, Safrizal $^{2}$ \\ ${ }^{1}$ Guru Kelas, Sekolah Dasar Negeri 025 Sinambek, Kabupaten Kuantan Singingi, Riau \\ ${ }^{2}$ Program Studi Pendidikan Guru Sekolah Dasar, Institut Agama Islam Negeri Batusangkar \\ e-mail: diah15124016@gmail.com
}

\begin{abstract}
ABSTRAK. Penelitian ini dilatar belakangi berdasarkan hasil analisis bahan ajar membaca pemahaman di kelas VI Sekolah Dasar (SD) ditemui beberapa permasalahan tentang bahan ajar menulis narasi salah satunya bahan ajar yang digunakan belum memuat tahapan membaca yang semestinya serta bahan ajar belum dikembangkan secara maksimal. Hal tersebut dapat menyebabkan guru harus mampu mengembangkan bahan ajar sebagai sarana dalam membantu proses pembelajaran yang dapat meningkatkan keterampilan membaca peserta didik. Tujuan yang hendak dicapai dalam upaya pengembangan bahan ajar ini adalah menghasilkan bahan ajar membaca pemahaman yang valid, praktis, dan efektif. Jenis penelitian ini adalah penelitian pengembangan. Penelitian ini menggunakan model ADDIE yang terdiri dari 5 tahap yaitu: tahap Analisis (analysis), perancangan (design), pengembangan (development), implementasi (implementation) dan Evaluasi (Evaluation). Data penelitian dari uji validitas diperoleh melalui lembar validasi bahan ajar. Data kepraktisan diperoleh dari melalui lembar keterlaksanaan RPP, penilaian respon guru dan penilaian peserta didik. Keefektifan dilihat dari aktivitas, penilaian proses membaca pemahaman, dan penilaian hasil membaca pemahaman. Berdasakan uji validitas diperoleh data bahwa persentase rata-rata bahan ajar dari validator ahli dan validator praktisi. Persentase validator ahli adalah 91,5\% dengan kategori sangat valid dan persentase praktisi pendidikan adalah 91,9\% dengan kategori sangat valid. Hasil uji praktikalitas dari keterlaksanaan RPP diperoleh persentase 90,1\% dengan kategori sangat praktis. Penilaian respon guru diperoleh persentase 90,3\% dan penilaian respon peserta didik adalah 88,8\% dengan kategori sangat praktis. Efektifitas bahan ajar dilihat dari aktivitas peserta didik diperoleh rata-rata persentase $82,5 \%$ dengan kategori sangat baik. Dari penilaian proses membaca pemahaman diperoleh persentase $83,3 \%$ dengan kategori sangat tinggi. Dari penilaian hasil membaca pemahaman diketahui bahwa persentase ketuntasan hasil membaca pemahaman peserta didik cenderung meningkat. Berdasarkan hasil tersebut, dapat disimpulkan bahan ajar membaca pemahaman menggunakan strategi TPRC (Think, Predict, Read, Connect) di kelas VI Sekolah Dasar yang dikembangkan dapat dinyatakan valid, praktis, dan efektif.
\end{abstract}

Kata kunci: Pengembangan Bahan Ajar, Strategi TPRC, Keterampilan Membaca Pemahaman,

\section{PENDAHULUAN}

Bahasa Indonesia merupakan bahasa yang mempunyai peranan penting dalam berkomunikasi baik secara lisan maupun tulisan. Seseorang dikatakan mampu berbahasa Indonesia apabila mampu menggunakan bahasa tersebut dengan baik. Bahasa Indonesia merupakan bahasa resmi Republik Indonesia yang dijadikan sebagai bahasa pengantar dalam kegiatan pembelajaran di sekolah. Pembelajaran bahasa Indonesia diarahkan untuk meningkatkan kemampuan peserta didik untuk berkomunikasi dalam bahasa Indonesia dengan baik dan benar dan menumbuhkan apresiasi terhadap hasil karya kesastraan manusia Indonesia. 
Pembelajaran bahasa Indonesia memuat empat aspek keterampilan berbahasa. Aspek keterampilan berbahasa tersebut yaitu mendengarkan, berbicara, membaca, dan menulis. Di antara keempat komponen tersebut keterampilan membaca di Sekolah Dasar (SD) memegang peranan penting dalam mengembangkan kemampuan berbahasa karena membaca dapat memperluas pengetahuan, wawasan, dan kemampuan seseorang. Melalui membaca akan membentuk kemampuan berfikir lewat proses menangkap gagasan atau informasi, memahami, mengimajinasikan, dan menerapkannya. Keterampilan membaca perlu diterapkan saat anak masih sedini mungkin karena membaca merupakan dasar utama yang harus dimiliki peserta didik.

Membaca merupakan suatu kegiatan yang berupaya untuk menemukan berbagai informasi yang terdapat dalam tulisan. Hal ini berarti membaca merupakan proses berfikir untuk memahami isi teks yang dibaca. Menurut Yunus (2013) membaca secara sederhana dikatakan sebagai proses membunyikan lambang bahasa tertulis. Dalam pengertian ini, membaca sering disebut sebagai membaca nyaring atau membaca permulaan. Membaca juga dapat dikatakan sebagai proses untuk mendapatkan informasi yang terkandung dalam teks bacaan untuk memperoleh pemahaman atas isi bacaan. Proses yang dilakukan serta dipergunakan oleh pembaca untuk memperoleh pemahaman atas isi bacaan yang hendak disampaikan oleh penulis melalui media kata$\mathrm{kata} / \mathrm{bahasa}$ tulis.

Membaca pemahaman merupakan salah satu jenis kegiatan membaca dan harus dilakukan dengan teknik membaca yang benar. Menurut Somadayo (2011:10) membaca pemahaman merupakan proses pemerolehan makna bacaan secara aktif dengan melibatkan pengetahuan dan pengalaman yang dimiliki oleh pembaca. Pengetahuan dan pengalaman tersebut dihubungkan dengan isi bacaan. Hal ini berarti ada beberapa hal pokok dalam membaca pemahaman, yaitu usaha atau motivasi untuk memperoleh makna, memahami isi bacaan yang melibatkan pengetahuan dan pengalaman pembaca, proses menghubungkannya dengan isi bacaan serta bahan ajar yang digunakannya.

Bahan ajar yang digunakan dalam proses pembelajaran merupakan segala bentuk yang digunakan untuk membantu guru dalam melaksanakan kegiatan belajar mengajar. Menurut Depdiknas (2008) bahan ajar berfungsi sebagai (1) pedoman bagi guru yang akan mengarahkan semua aktivitasnya dalam proses pembelajaran, sekaligus sebagai substansi kompetensi yang harus diajarkan kepada peserta didik, (2) pedoman bagi peserta didik yang akan mengarahkan semua aktivitasnya dalam proses pembelajaran dan merupakan substansi kompetensi yang harus dikuasai, dan (3) sebagai alat evaluasi pencapaian hasil pembelajaran. Proses pembelajaran membaca pemahaman tidak terlepas dari peran guru dalam pembelajaran. Dalam proses pembelajaran guru hendaknya harus menyiapkan diri dalam menyajikan bahan ajar, menentukan kegiatan yang akan dilakukan bersama peserta didik, mampu meningkatkan keterampilan membaca peserta didik terutama pada membaca pemahaman, dan sebagai sarana penunjang dalam pembelajaran agar mencapai tujuan yang hendak dicapai.

Berdasarkan hasil wawancara dan observasi yang dilakukan penulis pada beberapa guru dan peserta didik di MIN Gunung Pangilun ditemukan beberapa permasalahan dalam pembelajaran membaca yaitu pertama, pembelajaran yang dilakukan guru kurang mengacu pada tahapan membaca yang semestinya yaitu prabaca, saat baca dan pascabaca. Hal ini terlihat pada Indikator yang terdapat pada RPP yang digunakan guru dalam pembelajaran. Kedua, bahan ajar yang digunakan guru kurang mengarahkan peserta didik melakukan prediksi terhadap gambar dan judul bahan bacaan yang akan dibaca. Ketiga, guru sudah terbiasa mengambil materi sebagai bahan ajarnya dari buku teks atau buku pelajaran yang telah disediakan sekolah sehingga belum menggambarkan proses dari membaca. Keempat, pendekatan yang digunakan dalam bahan ajar membaca pemahaman belum menggunakan inovasi dan strategi terbaru yang menarik minat peserta didik. Kelima, bahan ajar yang digunakan guru belum terlihat petunjuk-petunjuk yang jelas dalam menyelesaikan tugas-tugas. Hal ini berujung pada sulitnya peserta didik dalam memahami isi bacaan. 
Masalah pembelajaran membaca di atas, juga ditemukan dalam jurnal Internasional hasil penelitian oleh Evan Ortlieb, dkk (2013) antara lain (1) ketergantungan guru terhadap buku teks masih sangat tinggi, (2) peserta didik kesulitan menemukan makna dari sebuah teks, sulit memperoleh informasi dari teks yang dibaca dan peserta didik mengalami kesulitan dalam menemukan gagasan utama, mengajukan pertanyaan, membuat prediksi, dan menarik kesimpulan atau rangkuman dari apa yang telah dibacanya, dan (3) guru belum memfokuskan peserta didik pada teks bacaan. Hal lain yang ditemukan bahwa bahan ajar yang digunakan sekolah tersebut dalam pembelajaran kurang sesuai dengan kebutuhan peserta didik dan karakteristik peserta didik. Guru hanya menggunakan dua buku penunjang yaitu buku karangan UN dan HN. Walaupun guru sudah memiliki buku penunjang lebih dari satu, tetapi dalam buku tersebut masih terlihat kurang sesuai dengan kebutuhan peserta didik.

Bahan ajar juga kurang memuat proses membaca dengan lengkap, yaitu: prabaca, saat baca, dan pascabaca. Saat prabaca, peserta didik tidak diminta memprediksi berdasarkan judul. Kemudian indikator pada RPP dan bahan ajar juga kurang sesuai dengan SK, KD yang ingin dicapai. KD yang ingin dicapai yaitu KD 3.1. Mendeskripsikan isi penyajian suatu laporan hasil pengamatan/kunjungan. Sementara pada materi, peserta didik diminta untuk langsung menjawab pertanyaan tanpa melewati tahap-tahap dari proses membaca itu sendiri. Hal ini berarti, kurang tepatnya materi dengan KD yang ingin dicapai. Selain itu, dilihat dari segi desain, bahan ajar yang digunakan cenderung monoton dan kurang menarik minat peserta didik untuk membaca pemahaman. Bahan ajar juga terlihat hanya menggunakan satu warna sehingga kurang sesuai dengan karakteristik peserta didik yang diusianya menyukai warna-warna cerah dan gambargambar yang menarik.

Idealnya, bahan ajar yang digunakan oleh guru hendaklah sesuai dengan kebutuhan kurikulum dan tahapan membaca yaitu: tahap prabaca meliputi kegiatan memprediksi isi bacaan dan membuat pertanyaan sesuai prediksi bacaan dan menuliskan pokok-pokok isi bacaan. Tahap pascabaca meliputi kegiatan meyimpulkan isi bacaan dan menjawab pertanyaan berdasarkan isi bacaan. Berdasarkan uraian tersebut diperlukan pengembangan bahan ajar dengan menggunakan strategi yang tepat untuk keterampilan membaca pemahaman. Bahan ajar yang memuat variasi pembelajaran keterampilan membaca pemahaman yang dapat membantu peserta didik dalam memahami isi bacaan yang berfokus pada penemuan makna dari sebuah teks, memperoleh informasi dari teks, menemukan gagasan utama, mengajukan pertanyaan, membuat prediksi, dan menarik kesimpulan atau rangkuman dari apa yang telah dibacanya. Strategi pembelajaran yang cocok digunakan untuk mengembangkan bahan ajar membaca pemahaman adalah Stratagi TPRC (Think, Predict, Read, Connect). Menurut Ruddel (2005) TPRC a strategy that helps students develop their general knowledge before, during, and after reading. The students think about the topic, predict what will happen in the text, read the text, and then make connections to their own lives. Students can use TPRC with all informational texts. Strategi ini peserta didik melakukan proses berfikir, memprediksi, membaca dan mengkoneksikan apa yang sudah dibaca dengan isi bacaan. Strategi ini membuat peserta didik berfikir tentang topik, memprediksi apa yang akan terjadi dalam teks, membaca teks dan kemudian membuat koneksi ke kehidupan mereka sendiri. Strategi TPRC akan membantu peserta didik memiliki cara yang lebih baik untuk memahami suatu bagian, sehingga hasil pembacaan akan lebih efektif.

Pembelajaran membaca dengan menggunakan strategi TPRC akan menumbuhkan antusias peserta didik, karena di dalamnya terdapat langkah predict. Langkah predict akan membuat peserta didik berlomba untuk bisa memprediksi isi bacaan dengan tepat. Strategi TPRC juga memiliki langkah connect yang akan membentuk konsep pemahaman utuh tentang isi bacaan. Peserta didik akan mengkoneksikan pengetahuan awal sebelum membaca dengan pengetahuan yang dimiliki setelah membaca. Dengan begitu, peserta didik akan memiliki pemahaman yang utuh yang terbentuk dari aktivitas pembelajaran yang mereka laksanakan. Bahan ajar merupakan seperangkat materi pembelajaran yang disusun secara sistematis yang digunakan untuk pencapaian setiap kompetensi dasar yang ditetapkan. Menurut Kemendiknas (2011) bahan ajar adalah segala bentuk 
bahan yang digunakan untuk membantu guru dalam melaksanakan proses pembelajaran. Akan tetapi, bahan ajar yang digunakan hendaknya tidak hanya sekedar membantu proses pembelajaran namun melihat secara utuh ketercapaian kompetensi dasar yang dikembangkan.

Hal senada dikemukakan Hamdani (2011) bahwa bahan ajar adalah segala bentuk bahan atau materi yang disusun secara sistematis yang digunakan untuk membantu guru atau instruktur dalam melaksanakan proses pembelajaran sehingga tercipta lingkungan atau suasana yang memungkinkan peserta didik untuk belajar. Berdasarkan paparan di atas maka pengertian bahan ajar adalah bahan ajar atau materi yang dikembangkan menyerupai buku dengan memperhatikan komponen-komponen yang ada didalamnya. Pada penelitian ini bahan ajar yang akan dikembangkan adalah bahan ajar membaca pemahaman menggunakan strategi TPRC di Kelas VI Sekolah Dasar. Bahan ajar harus dipilih dan disusun secara tepat agar dapat menunjang ketercapaian kompetensi dasar dan secara spesifik dipilih berdasarkan rumusan indikator yang diinginkan. Oleh karena itu, harus diketahui cara dan langkah yang tepat dalam memilih bahan ajar yang ingin dikembangkan. Seperti yang dikemukakan oleh Susanto (2007), bahwa pemilihan bahan ajar dilakukan setelah perumusan indikator dilakukan, bukan sebaliknya, karena tujuan akhir setiap proses pembelajaran adalah penguasaan kompetensi. Pemilihan bahan ajar yang mendahului perumusan indikator akan sulit dilakukan karena hanya berdasarkan pada satu kompetensi dasar yang rumusannya masih sangat umum.

Bahan ajar yang akan dikembangkan dalam penelitian ini adalah bahan ajar membaca pemahaman menggunakan strategi TPRC yang disajikan dan dikemas berdasarkan tahap membaca dan langkah TPRC yang digunakan. Pengembangan bahan ajar yang dilakukan disesuaikan dengan komponen-komponen yang terdapat dalam bahan ajar. Membaca teks tidak hanya membaca seluruh kalimat di dalamnya, tetapi juga mendapatkan informasi dari apa yang telah dibaca. Salah satu jenis kegiatan membaca adalah membaca pemahaman. Tujuan utama dari membaca pemahaman tentu untuk memahami isi bacaan secara mendalam. Menurut Somadayo (2011) mendefinisikan membaca pemahaman sebagai proses pemerolehan makna bacaan secara aktif dengan melibatkan pengetahuan dan pengalaman yang dimiliki oleh pembaca. Pengetahuan dan pengalaman tersebut dihubungkan dengan isi bacaan. Sementara, Alexander (1988) mengatakan bahwa pemahaman adalah jenis khusus dari proses berpikir yang secara aktif dapat membangun makna internal dari berinteraksi dengan materi yang dibaca.

Hal ini berarti Membaca pemahaman adalah keterampilan untuk memahami informasi dalam teks dan menafsirkannya dengan tepat. Mendapatkan informasi dari bahan bacaan bisa sangat sulit jika pembaca tidak dapat memahami apa yang mereka baca. Menurut Agustina (2008) mengungkapkan bahwa membaca pemahaman mempunyai tujuan mengungkapkan isi, atau makna dari gagasan-gagasan yang terdapat dalam bacaan yang berbentuk pengertianpengertian dan penafsiran-penafsiran yang tidak meyimpang dari bacaan itu. Hal senada diutarakan oleh Somadayo (2011) bahwa tujuan utama membaca pemahaman adalah untuk memperoleh pemahaman. Selain itu, Menurut Tarigan (2008) tujuan utama dalam membaca pemahaman adalah untuk mencari serta memperoleh informasi, mencakup isi, memahami makna bacaan. Menurut Bruns (dalam Taufina, 2015) ada 3 tahap dalam membaca, yaitu: (1) prabaca (prereading), (2) saat baca (during-reading),dan (3) pascabaca (post-reading). Menurut Saddhono (2012) tahapan prabaca merupakan kegiatan yang dilakukan sebelum kegiatan inti membaca untuk membangkitkan pengetahuan awal maupun pengetahuan yang relevan yang telah dimiliki peserta didik dalam rangka membangun pemahaman pembaca mengenai isi teks. Tahapan saat baca menurut Abidin (2012) salah satu kegiatan yang dilakukan pada kegiatan membaca yaitu menemukan inti gagasan. Sedangkan tahapan pascabaca menurut Saddhono (2012) salah satunya adalah menjawab isi bacaan. Salah satu alternatif yang tepat untuk menembangkan bahan ajar membaca pemahaman adalah menggunakan strategi TPRC. Menurut Lenski (dalam Sethna, 2011) TPRC a strategy used to develop their general knowledge before, during, and after reading. Artinya, strategi TPRC ini digunakan untuk mengembangkan pengetahuan umum peserta didik sebelum, selama, dan setelah membaca. 


\section{METODOLOGI}

Jenis penelitian ini adalah penelitian pengembangan (Research and Development). Menurut Borg \& Gall (dalam Putra, 2011), penelitian pengembangan (Research and Development) dalam pendidikan adalah sebuah model pengembangan berbasis industri di mana temuan penelitian digunakan untuk merancang produk dan prosedur baru, yang dikemudian secara sistematis diuji di lapangan, dievaluasi, dan disempurnakan sampai memenuhi kriteria efektivitas dan berkualitas. Penelitian ini dilaksanakan untuk mengembangkan suatu produk berupa bahan ajar dalam pembelajaran membaca pemahaman dengan strategi TPRC. Model pengembangan yang digunakan pada penelitian ini mengacu pada model ADDIE, yang dikemukakan oleh Pribadi (2011:128) model ini terdiri dari lima tahap, yaitu analisis (analysis), desain (design), pengembangan (development), implementasi (implementation), dan evaluasi (evaluation). Tahap implementasi dilakukan pada skala terbatas, yaitu pada kelas VI SDN 16 Air Tawar Timur karena keterbatasan biaya dan waktu.

\section{TEMUAN DAN DISKUSI}

Pengembangan bahan membaca pemahaman menggunakan strategi TPRC di Kelas VI dengan menggunakan model $A D D I E$. Deskripsi data hasil penelitian dijelaskan sebagai berikut:

\section{Tahap Analisis}

Pada tahap menganalisis dilakukan analisis yang terdiri dari 3 aspek yang meliputi: analisis kinerja, analisis kebutuhan, dan analisis peserta didik. Analisis kinerja dilakukan telaah terhadap Kurikulum Satuan Tingkat Pendidikan (KTSP) untuk mata pelajaran bahasa Indonesia kelas VI SD. Analisis kurikulum diperlukan untuk mempelajari cakupan meteri, tujuan pembelajaran, pemilihan strategi yang sesuai dengan landasan untuk mengembangkan bahan ajar. Berdasarkan permendiknas No. 22 Tahun 2006, kurikulum yang dikembangkan sesuai dengan prinsip-prinsip pengembangan yang berpusat pada kepentingan peserta didik dan lingkungan, beragam dan terpadu, relevan dengan kebutuhan dan kehidupan. Analisis kurikulum yang peneliti lakukan difokuskan pada analisis SK dan KD pada materi membaca pemahaman di kelas VI SD sesuai dengan kurikulum yang berlaku. SK yang diambil adalah: 3. Memahami teks dengan membaca intensif dan membaca sekilas. Sedangkan KD yang diambil adalah: 3.1 Mendeskripsikan isi suatu laporan hasil kunjungan melalui membaca intensif Hasil dari analisis SK dan KD tentang membaca pemahaman di kelas VI SD tersebut, dijabarkan menjadi indikator-indikator dan tujuan pembelajaran. Penyusunan indikator dan tujuan pembelajaran disusun berdasarkan proses dan tahapan membaca. Analisis kebutuhan bertujuan untuk mengetahui masalah dasar yang dibutuhkan dalam pengembangan bahan ajar. Salah satunya menganalisis bahan ajar yang digunakan disekolah dasar. Analisis kebutuan yang peneliti lakukan adalah dengan menganalisis bahan ajar yang beredar dan digunakan di sekolah. Analisis yang dilakukan pada bahan ajar melihat dua aspek utama, yaitu isi teks (content) dan desain (tampilan dan redaksi).

Isi teks merupakan ketepatan dan keakuran informasi yang disajikan dalam teks. Sedangkan desain merupakan cara mengungkapkan dan menampilkan bahan sehingga mempunyai tingkat keterbacaan yang menarik dan memotivasi peserta didik. proses pembelajaran membaca pemahaman yang diberikan. Analisis karakteristik peserta didik dalam penelitian ini dilakukan pada aspek perkembangan bahasa peserta didik, perkembangan intelektual, dan halhal yang dapat meningkatkan motivasi belajar peserta didik. Menganalisis tingkat perkembangan bahasa peserta didik digunakan untuk pertimbangan dalam menyusun bahasa. Menganalisis perkembangan intelektual peserta didik digunakan untuk pertimbangan dalam menyusun tingkat kesukaran masalah dalam bahan ajar. Sedangkan menganalisis motivasi belajar peserta didik digunakan untuk pertimbangan dalam merancang penyajian bahan ajar yang mengundang ketertarikan atau membuat peserta didik termotivasi dalam belajar. Hasil analisis karakteristik peserta didik yang dilakukan adalah usia peserta didik kelas VI MIN Gunung Pangilun berada antara 10-12 tahun. Perkembangan bahasa peserta didik kelas VI MIN Gunung Pangilun telah mampu berargumentasi, berkomunikasi dengan baik dan sudah memiliki 
struktur bahasa yang kompleks serta mampu memahami berbagai aturan tata bahasa yang baik dan benar walaupun terkadang peserta didik sesekali menggunakan bahasa daerah ketika peneliti melakukan wawancara. Berdasarkan perkembangan intelektual menurut Piaget, peserta didik pada jenjang usia tersebut berada pada tingkat perkembangan akhir operasional kongkrit sampai pada awal operasional formal. Peserta didik pada usia ini telah mampu berpikir abstrak dan logis, mampu melakukan pengelompokkan, menyukai penelitian dan pengujian untuk menyelesaikan suatu masalah.

Analisis perkembangan kognitif peserta didik dilakukan dengan mewawancarai beberapa orang peserta didik. Wawancara yang dilakukan adalah wawancara tidak terstruktur, yaitu wawancara yang dilakukan tanpa menggunakan pedoman wawancara melainkan berkembang berdasarkan jawaban responden sehingga mampu menggali informasi yang lebih dalam. Wawancara yang dilakukan mengetahui pemahaman peserta didik tentang pembelajaran membaca pemahaman Berikut akan dipaparkan hasil wawancara peneliti dengan beberapa orang peserta didik di kelas VI SDN MIN Gunung Pangilun. Berdasarkan hasil wawancara yang dilakukan, diperoleh berbagai informasi terkait bahan ajar yang dibutuhkan oleh peserta didik dalam pembelajaran membaca di kelas VI SD. Beberapa hal yang dapat diungkap antara lain: di dalam teks banyak penggunaan istilah yang kurang dipahami, isinya banyak menggambarkan dari daerah lain sehingga kurang kontekstual jika dikaitkan dengan daerah setempat, teknik membaca yang belum diterapkan dengan baik, tahapan membaca yang kurang dikondisikan dengan baik, dan warna beserta gambar bahan ajar yang kurang menarik.

\section{Tahap Design}

Format dan penyusunan bahan ajar ini dimodifikasi dari struktur bahan ajar menurut Depdiknas yang terdiri atas: (1) cover, (2) kata pengantar, (3) daftar isi, (4) petunjuk penggunaan, (5) SK dan KD yang akan dicapai, (6) judul, (7) tujuan yang akan dicapai, (8) tugas-tugas atau kegiatan, (9) informasi pendukung, dan (10) daftar pustaka.

Cover bahan ajar didesain dengan warna hijau dikombinassi dengan warrna biru. Warna hijau dan biru mempunyai karakteristik yang hampir sama Warna biru memiliki karakteristik kesegaran, pertumbuhan, sejuk, tenang dan damai. Warna hijau dikombinasi dengan biru dipilih agar ketika melihat bahan ajar peserta didik langsung tertarik untuk mempelajarinya. sedangkan tulisan membaca pemahaman didesain dengan warna hijau. Selain itu, pada cover juga disajikan tiga gambar ikon utama disertai dengan gambar pohon yang besar. Yang pertama gambar anak lakilaki dan perempuan yang dimaknai sedang membaca buku. Yang kedua anak laki-laki yang berada di depan buku dan melihat teman-temannya membaca. Di tengah-tengah terdapat pohon besar yang di daunya terdapat buku, globe, pensil, pena, penggaris. Semuanya itu berarti dengan membaca buku kita bisa mendapatkan berbagai informasi

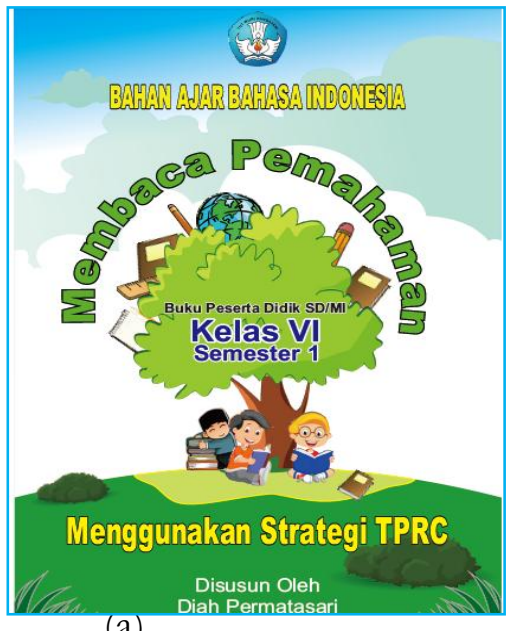

(a)

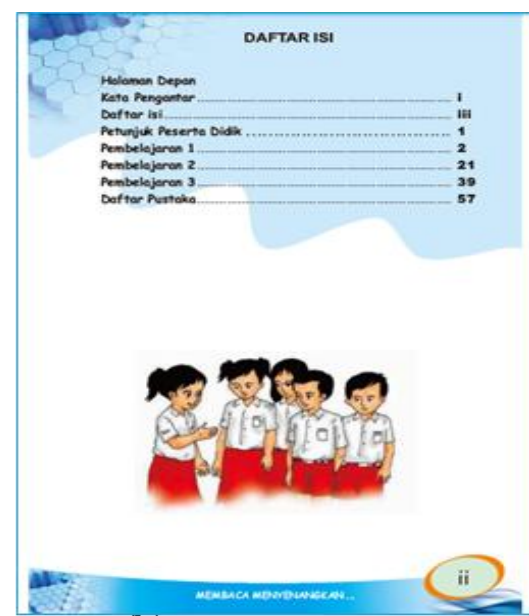

(b)

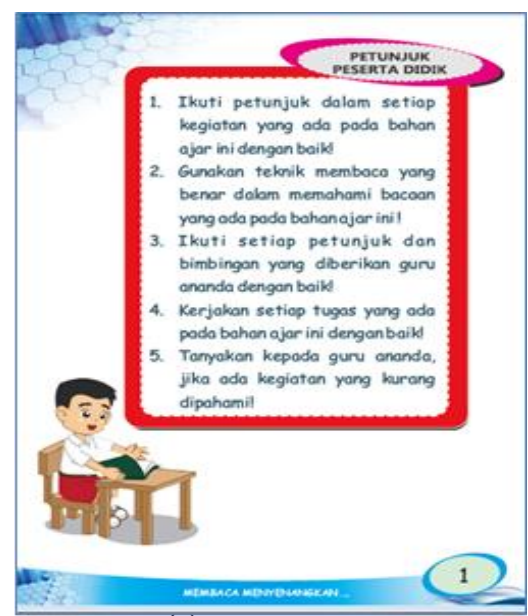

(c)

Gambar 1. (a) Cover Bahan Ajar, (b) Daftar Isi, (c) Petunjuk Peserta Didik 
Bahan ajar dilengkapi dengan uraian materi yaitu mengenai membaca pemahaman menggunakan strategi TPRC. Informasi pendukung atau materi ini bertujuan untuk menambah pemahaman peserta didik mengenai materi membaca pemahaman serta tahapan membaca pemahaman menggunakan strategi TPRC.

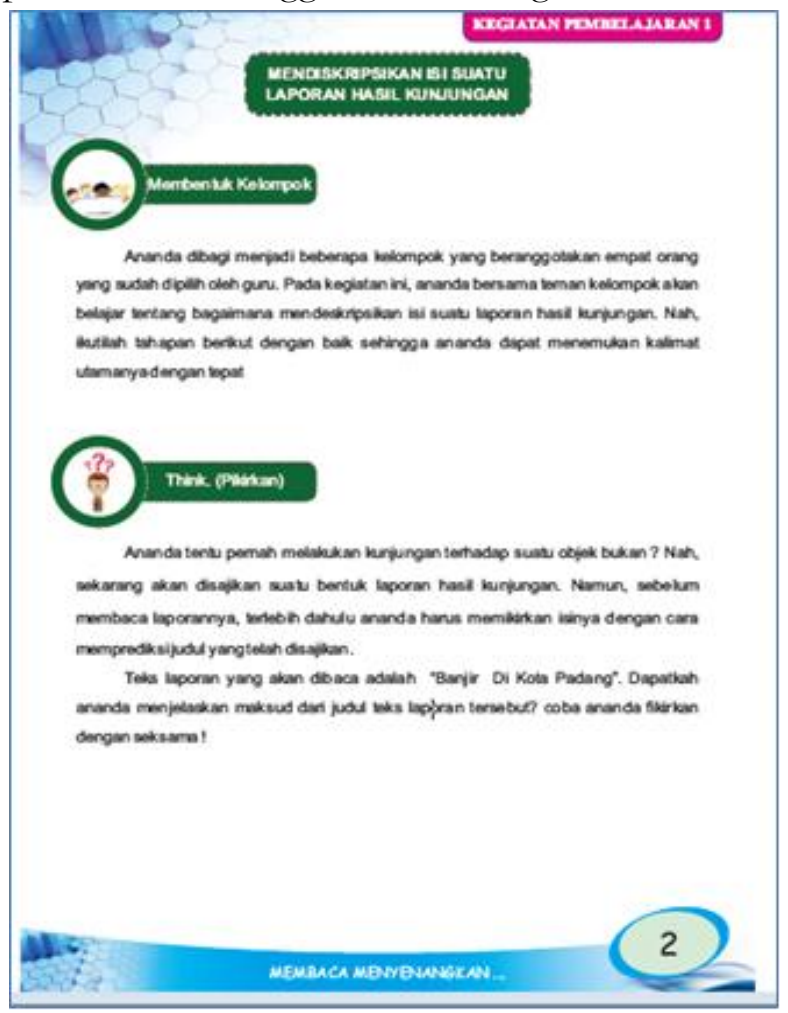

(a)

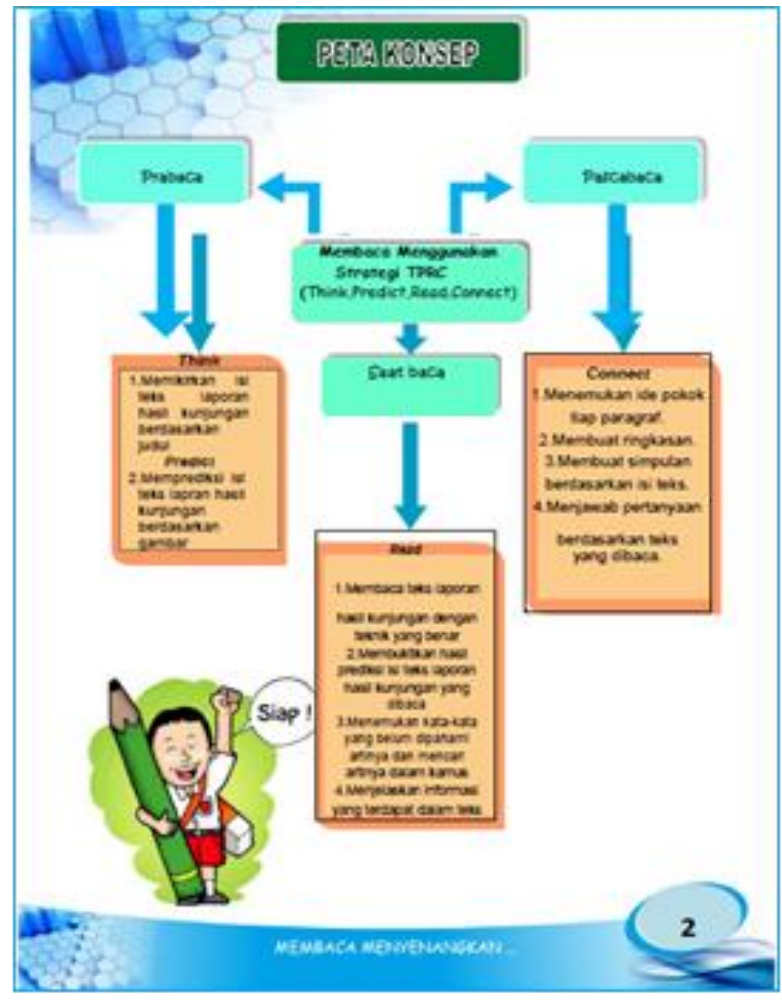

(b)

\section{Gambar 2. (a) Informasi Pendukung Materi, (b) Peta Konsep}

\section{Tahap Develop (Pengembangan)}

Tahap pengembangan meliputi validasi bahan ajar dan RPP selajutnya dilakukan uji coba produk untuk melihat praktikalitas dan efektivitas bahan ajar yang dikembangkan. Pengujian validitas yaitu dengan memvalidasi bahan ajar oleh para pakar dan praktisi, kemudian dilakukan revisi. Pengujian praktikalitas yaitu dengan mengujicobakan bahan ajar yang telah dikembangkan dalam proses pembelajaran di kelas. Validasi RPP dilakukan terhadap beberapa aspek yang meliputi identitas, perumusan indikator, perumusan tujuan pembelajaran, pemilihan materi pembelajaran, pemilihan sumber dan media pembelajaran, penyusunan kegiatan pembelajaran, dan penilaian. Hasil validasi RPP oleh validator ahli untuk aspek identitas dapat dilihat pada tabel berikut.

Tabel 1. Hasil Validasi RPP Oleh Ahli

\begin{tabular}{lcl}
\hline Aspek yang Dinilai & Nilai Validasi (\%) & Kategori \\
\hline Aspek Identitas & 91,6 & Sangat Valid \\
Aspek Perumusan Indikator & 88,9 & Sangat Valid \\
Aspek Perumusan Tujuan Pembelajaran & 94,4 & Sangat Valid \\
Aspek Pemilihan Materi pembelajaran & 86,1 & Sangat Valid \\
Aspek Pemilihan Media dan Sumber Belajar & 75 & Valid \\
Aspek Penyusunan Kegiatan Pembelajaran & 90 & Sangat Valid \\
Aspek Penilaian & 86,1 & Sangat Valid \\
\hline Rata-rata & $\mathbf{8 7 , 4}$ & Sangat Valid \\
\hline
\end{tabular}

\section{Tahap Implementasi}


Tahap implementasi dilakukan setelah melakukan tahap pengembangan dengan bahan ajar yang telah direvisi. Implementasi merupakan langkah nyata penerapan bahan ajar dalam kelas. Tahap Implementasi dilakukan pada SDN 16 Air Tawar Timur. Tujuan implementasi ini adalah untuk menguji efektivitas penggunaan bahan ajarr tersebut pada objek, situasi, dan kondisi yang berbeda. Tahap Implementasi dilakukan di kelas VI SDN 16 Air Tawar Timur. Penerapan uji efektivitas yang dilakukan pada tahap Implementasi sama halnya ketika uji efektivitas ketika uji coba produk dilakukan. Ada dua hal pokok yang perlu menjadi bahan pertimbangan, yaitu aktivitas dan penilaian keterampilan membaca pemahaman peserta didik. Berikut ini dipaparkan lebih lanjut mengenai implementasi bahan ajar yang telah dilakukan. tahap implementasi juga dinilai hasil belajar yang sama, yaitu penilaian proses dan penilaian hasil.

Penilaian proses difokuskan pada penilaian proses keterampilan membaca pemahaman dengan menggunakan rubrik penilaian yang telah disiapkan sebelumnya. Sedangkan pada Penilaian hasil keterampilan membaca merupakan penilaian pemahaman peserta didik terhadap isi bacaan yang dibaca. Penilaian yang dilakukan dengan memberikan soal-soal evaluasi terkait dengan teks yang dibaca. Untuk lebih jelasnya dapat diuraikan sebagai berikut.

Tabel 2. Hasil Praktikalitas dan Efektivitas Bahan Ajar Berbasis TPRC

\begin{tabular}{lcc}
\hline \multicolumn{1}{c}{ Indikator Penilaian } & Rata-rata & Kategori \\
\hline Tahap Prabaca & & Tinggi \\
Memprediksi Isi Bacaan & 72,7 & \\
Tahap Saat Baca & & Sangat Tinggi \\
Mengisi makna kata yang belum di pahami & 86,1 & Sangat Tinggi \\
Menguji Prediksi & 92,1 & \\
Tahap pasca baca & & Sangat Tinggi \\
Meringkas Isi bacaan & 88,9 & Tinggi \\
Menulis Simpulan Teks Bacaan & 75,9 & Sangat Tinggi \\
\hline Rata-rata & $\mathbf{8 3 , 2}$ & \\
\hline
\end{tabular}

Tabel di atas Pada tahap prabaca, aspek yang dinilai adalah kegiatan memprediksi isi bacaan sebelum membaca. Pada kegiatan memprediksi isi bacaan diperoleh nilai rata-rata $72,7 \%$ dengan kategori Tinggi. Hal ini memberikan gambaran bahwa peserta didik sebagian besar mengisi lembar prediksi isi teks hampir secara keseluruhan. Mereka memikirkan dan memprediksi bacaan melalui judul dan gambar yang mendukung terkait dengan teks bacaan yang akan dibaca pada bahan ajar. Pada tahap saat baca, terdapat dua aspek utama yang dinilai, yaitu mengisi makna kata yang belum dipahami dan menguji prediksi,. Pada kegiatan mengisi makna kata yang belum dipahami diperoleh nilai rata-rata $86,1 \%$ dengan kategori sangat tinggi. Selanjunya, pada kegiatan menguji prediksi diperoleh nilai rata-rata $92,1 \%$ dengan kategori sangat tinggi. Berdasarkan paparan tersebut, dapat disimpulkan bahwa peserta didik dapat mengikuti kegiatan proses membaca dengan baik dalam memahami isi bacaan.

Pada tahap pascabaca, terdapat dua aspek yang dinilai adalah kegiatan meringkas isi bacaan dan menuliskan simpulan teks bacaan. Pada kegiatan meringkas isi bacaan diperoleh nilai rata-rata 88,9 \% dengan kategori Sangat tinggi dan pada kegiatan menuliskan simpulan teks bacaan diperroleh nilai rata-rata $75,9 \%$ dengan kategori tinggi Peserta didik telah dapat meringkas isi teks secara keseluruhan dengan baik secara runtut. Isi ringkasan yang telah dibuat sudah dapat menggambarkan isi teks secara keseluruhan dan sebagian besar peserta didik sudah bisa membuat simpulan dengan bahasanya sendiri. Dengan demikian, pada tahap pascabaca peserta didik dapat mengikuti kegiatan dengan baik. Berdasarkan paparan di atas, jika dilihat dari penilaian proses keterampilan membaca, proses pembelajaran membaca pemahaman menggunakan strategi TPRC dapat berjalan dengan baik dan dapat mencapai hasil yang diharapkan. Dengan demikian, bahan ajar yang dikembangkan jika dilihat dari penilaian proses sudah efektif dilaksanakan pada ruang lingkup yang lebih luas yaitu pada sekolah lain dengan lingkungan dan kondisi yang berbeda. 


\section{Tahap Evaluasi}

Pada tahap ini evaluasi yang dilakukan adalah evaluasi sumatif dan formatif. Berikut ini akan dipaparkan evaluasi pada pengembangan bahan ajar. Evaluasi formatif dilakukannya revisi pada saat bahan ajar di validasi oleh validator. Hasil evaluasi berupa revisi bahan ajar oleh validator. Secara umum bahan ajar yang sudah dikembangkan sudah dikatorikan sangat valid, hal ini terlihat dari lembar validasi yang sudah divalidasi oleh para validator. Hasil dari masukan dan diskusi dari validator sudah peneliti revisi. Hasil akhir dari evaluasi ini yaitu menghasilkan bahan ajar yang valid. Evaluasi sumatif dilakukan diakhir penggunaan bahan ajar dengan tujuan untuk melihat dampak penggunaan bahan ajar dan untuk mengetahui efektivitas bahan ajar yang sudah dikembangkan. Efektivitas bahan ajar yang sudah dikembangkan dilihat dari aktivitas peserta didik, keterampilan proses membaca dan penilaian hasil belajar peserta didik. Hal ini terlihat dari tahap uji coba dan implementasi. Hasil dari tahap uji coba dan implementasi terlihat bahwa bahan ajar membaca pemahaman menggunakan strategi TPRC sudah sangat efektif. Hal ini terlihat dari peningkatan aktivitas peserta didik, keterampilan proses membaca dan penilaian hasil belajar peserta didik dari setiap pertemuan.

\section{PEMBAHASAN}

Bahan ajar yang telah dikembangkan dikatakan valid apabila memenuhi kriteria tertentu. Menurut Plomp (2007) karakteristik dari produk yang dikatakan valid apabila ia merefleksikan jiwa pengetahuan (state of the art knowledge). Hal inilah yang dikatakan dengan validasi isi (content validiy). Selanjutnya, komponen-komponen produk tersebut harus konsisten satu sama lain (validitas konstruk). Oleh sebab itu, validasi yang dilakukan terhadap bahan ajar membaca pemahaman menggunakan strategi TPRC ini menekankan pada isi dan konstruk. Dalam penelitian ini validasi dirinci lagi menjadi validasi produk yang dilakukan terhadap isi, bahasa, penyajian dan kegrafikaan. Validasi dalam penelitian ini dilakukan oleh 3 orang validator ahli dan 3 orang validator praktisi. Hal ini sesuai dengan pendapat Sugiyono (2009:414) yang menyatakan bahwa validasi produk dapat dilakukan oleh beberapa pakar atau tenaga ahli yang sudah berpengalaman untuk menilai produk baru yang dirancang, sehingga selanjutnya dapat diketahui kelemahan dan keunggulannya.

Berdasarkan hasil analisis data validasi bahan ajar oleh validator ahli dan validator praktisi diperoleh persentase 91,8\%. Jika dilihat dari kategori yang telah ditetapkan maka bahan ajar yang telah dikembangkan tergolong pada kategori sangat valid. Oleh sebab itu, bisa disimpulkan bahwa bahan ajar yang dikembangkan telah sesuai dengan tuntutan kurikulum. Penyajian materi telah sesuai dengan indikator yang dirumuskan dan sesuai dengan perkembangan peserta didik. Isi bahan ajar juga telah sesuai dengan materi pembelajaran membaca di kelas VI SD. Berbagai konsep dan penjabaran tugas-tugas yang terdapat dalam bahan ajar memudahkan peserta didik memahami isi bacaan secara tepat. Isi bahan ajar telah dapat mencapai kompetensi dasar yag dipilih. Selain itu, penggunaan bahasa dalam bahan ajar menggunakan kalimat yang sederhana dan lebih jelas sehingga mudah dipahami oleh setiap peserta didik. Kalimat demi kalimat menggunakan ejaan yang tepat. Kemudian, bahan ajar yang dikembangkan didesain dengan warna yang menarik sehingga dapat memotivasi peserta didik untuk mengikuti proses pembelajaran dengan baik. Dengan demikian, dapat disimpulkan bahwa bahan ajar yang dikembangkan telah dinyatakan valid dan dapat digunakan dalam proses pembelajaran membaca.

Selanjutnya, Praktikalitas bahan ajar berhubungan dengan kemudahan dalam menggunakan bahan ajar, mudah dipindahkan dan dibawa kemana-mana. Praktikalitas yang diamati adalah tingkat keterlaksanaan RPP, angket respon guru, angket respon peserta didik terhadap praktikalitas terhadap penggunaan bahan ajar. Sukardi (2011) mengemukakan bahwa suatu produk dikatakan praktis dapat dilihat dari kemudahan penggunaannya, daya tarik produk terhadap minat peserta didik dan mudah diinterpretasikan oleh guru. Untuk melihat apakah bahan ajar yang dikembangkan praktis atau tidak, dilakukan uji coba pada peserta didik kelas VI MIN Gunung Pangilun, Padang dan Implementasi di kelas VI SDN 16 Air Tawar Timur. Melihat 
RPP yang telah dikembangkan sebelumnya, maka proses pembelajaran dilakukan satu kali pertemuan dengan alokasi waktu 4x35 menit. Praktikalitas yang diamati adalah tingkat keterlaksanaan RPP, angket respon guru, angket respon peserta didik, dan hasil wawancara terhadap praktikalitas bahan ajar.

Sebuah bahan ajar dapat dikatakan efektif jika membawa efek atau pengaruh baik terhadap pencapaian tujuan pembelajaran. Menurut Firman (2000), keefektifan program pembelajaran ditandai dengan ciri-ciri sebagai berikut: (a) berhasil mengantarkan peserta didik mencapai tujuan-tujuan instruksional yang telah ditetapkan, (b) memberikan pengalaman belajar yang atraktif, melibatkan peserta didik secara aktif sehingga menunjang pencapaian tujuan instruksional, (c) memiliki sarana-sarana yang menunjang proses pembelajaran. Berdasarkan hasil uji efektifitas pada tahap pengembangan menunjukkan rata-rata hasil penilaian keterampilan membaca pemahaman telah menunjukkan persentase yang tinggi. Tingkat efektivitas bahan ajar juga diperkuat oleh data pada tahap Implementasi. Hasil analisis data terhadap aktivitas peserta didik selama mengikuti proses pembelajaran dari tiga kali pertemuan diperoleh nilai rata-rata 93,5\% dengan kategori sangat baik. Selanjutnya, penilaian proses keterampilan membaca pemahaman yang dilakukan diperoleh nilai rata-rata 83,2\% dengan kategori sangat tinggi.

Mendapatkan hasil yang sempurna memang merupakan hal yang tidak mudah diwujudkan dalam pelaksanaan penelitian ini, walaupun bahan ajar telah dibuat berdasarkan model dan prosedur, yang sesuai dengan jenis penelitian ini. Pada awalnya, peserta didik menghabiskan waktu terlalu banyak saat memprediksi berdasarkan judul dan gambar. Hal ini dikarenakan sesuatu hal yang baru bagi peserta didik. Akan tetapi pada pertemuan berikutnya peserta didik sudah memahami dan mampu memanfaatkan waktu dengan baik dan efektif. Selanjutnya pada tahap Implementasi dalam penelitian pengembangan, seharusnya dilakukan pada skala yang lebih besar. Namun karena keterbatasan waktu, tenaga, dan biaya, Implementasi yang dilakukan bersifat terbatas, yaitu pada satu sekolah lain yaitu SDN 16 Air Tawar Timur yang memiliki lingkungan yang berbeda dengan MIN Gunung Pangilun Padang.

\section{KESIMPULAN}

Validitas bahan ajar membaca pemahaman menggunakan strategi TPRC di kelas VI Sekolah Dasar yang dikembangkan pada penelitian ini valid dari segi isi dan konstruk. Hal ini sesuai dengan hasil validasi dari validator ahli dan validator praktisi pendidikan. Hasil ini memberi gambaran bahwa bahan ajar yang dikembangkan telah valid dan dapat digunakan dalam proses pembelajaran. Praktikalitas bahan ajar membaca pemahaman menggunakan strategi TPRC di kelas VI Sekolah Dasar secara keseluruhan pada kategori sangat praktis. Hal ini diperoleh dari hasil pengamatan keterlaksanaan RPP terhadap guru yang mengajar, respon guru, respon peserta didik, dan lembar observasi penggunaan bahan ajar. Hasil ini memberikan gambaran bahwa bahan ajar sangat praktis dan dapat membantu dalam melaksanakan proses pembelajaran membaca pemahaman di kelas VI Sekolah Dasar. Efektivitas bahan ajar membaca pemahaman menggunakan strategi TPRC di kelas VI Sekolah Dasar dapat diketahui melalui aktivitas peserta didik, penilaian proses, dan penilaian hasil membaca pemahaman peserta didik. Hasil pengamatan aktivitas peserta didik, penilaian proses, dan penilaian hasil membaca pemahaman peserta didik memberikan gambaran yang sangat baik, artinya penggunaan bahan ajar dalam pembelajaran membaca sudah efektif dilaksanakan. Penelitian ini telah menghasilkan bahan ajar membaca pemahaman menggunakan strategi TPRC yang valid, praktis, dan efektif. Pada dasarnya, penelitian ini memberikan gambaran dan masukan khususnya pada praktisi pendidikan karena dapat meningkatkan kualitas pembelajaran membaca. Bahan ajar yang telah dikembangkan ini juga dapat membuat pembelajaran membaca pemahaman menjadi lebih bermakna dalam situasi yang sesuai dengan tahap-tahap membaca dengan benar, yaitu tahap prabaca, saat baca, dan pascabaca..Tahapan yang terdapat pada strategi TPRC juga sangat membantu dalam mengeefektifkan pembelajaran membaca. Pada tahap awal, peserta didik diajak berfikir dan 
memprediksi isi bacaan sebelum mereka membaca teks secara utuh. Kegiatan seperti ini merupakan gambaran awal kegiatan membaca yang berisi informasi berkaitan dengan isi teks bacaan. Selain itu, kegiatan prediksi merupakan petunjuk untuk melakukan antisipasi yang dirancang dalam menstimulasi pikiran, berisi pertanyaan-pertanyaan deklaratif yang berkaitan dengan teks yang akan dibaca. Setelah melakukan prediksi, peserta didik kemudian membuktikan kebenaran isinya melalui membaca teks secara langsung. Kegiatan seperti ini memberikan kontribusi kepada peserta didik untuk menyerap informasi secara utuh melalui proses penemuan dan pembuktian secara langsung. Setelah membaca, peserta didik dapat menjawab pertanyaan, menyatakan gagasan utama, meringkas, mendiskusikan tanggapan mereka terhadap materi atau mendiskusikan bagaimana mengungkapkan kembali isi teks atau mengubah materi.

\section{REFERENSI}

Abbas, S. 2006. Pembelajaran Bahasa Indonesia yang Efektif di Sekolah Dasar. Jakarta: Depdiknas.

Abidin, Y. 2012. Pembelajaran Bahasa Berbasis Pendidikan Karakter. Bandung: Refika Aditama.

Ahmad, A. Z. 2012. Perencanaan Pembelajaran dari Desain sampai Implementasi. Yogyakarta:Pedagogia

Allen, K. E. \& L. R. 2008. Profil Perkembangan Anak. Terjemahan oleh Valentino. 2010. Jakarta: Indeks.

Arikunto, S. 2006. Prosedur Penelitian: Suatu Pendekatan Praktek. Jakarta: Rineka Cipta.

Cochrane, K. 2009. Teaching Reading-An Action Research Model. Practically Primary. Vol 14. Number 3. October 2009

Dahlan, D. 2012. Pengembangan Perangkat Pembelajaran Biologi Berbasis Quantum Learning pada materi system pencernaan untuk Sekolah Menengah Atas. Tidak diterbitkan. Padang: Universitas Negeri Padang

Dalman. 2013. Keterampilan Membaca. Jakarta: RajaGrafindo Persada

Danim, S. 2010. Perkembangan Peserta Didik. Bandung: CV. Alfabeta

Depdiknas. 2006. Panduan Penyusunan Kurikulum Tingkat Satuan Pendidikan. Jakarta: Depdiknas.

-----. 2008. Kamus Besar Bahasa Indonesia Pusat Bahasa. Jakarta: Gramedia Pustaka Utama. 2009. Pengembangan Bahan Ajar. Jakarta: Diklat Bimtek/KTSP.

Dimyati \& Mudjiono. 2006. Belajar dan Pembelajaran.Jakarta: Rineka Cipta

Edo. 2015. The Effectiveness of TPRC Strategy for Teaching Reading Comprehension of Descriptive Texts. Antologi UNNES Desember 2015

Emzir. 2008. Metodologi Penelitian Pendidikan. Jakarta: Raja Grafindo Persada

Hamdani. 2011. Strategi Belajar Mengajar. Bandung: Pustaka Setia.

Hartinah, S. 2010. Pengembangan Peserta Didik. Bandung: Refika Aditama.

Huda, M. 2013. Model-model Pengajaran dan Pembelajaran. Yogyakarta: Pustaka Belajar.

Istarani. 2012. 58 Model Pembelajaran Inovatif. Medan: Media Persada. Jossey-Boss Education.

Kemendiknas. 2011. Model Bahan Ajar Matematika untuk Sekolah Dasar. Jakarta: Dirjendikdas Kemendiknas.

Kolic, J. V. \& Bajšanski. I. 2006. Metacognitive Strategies and Reading Comprehension in Elementary School Students. European Journal of Psychology of Education European Journal of Psychology of Education 2006, Vol. 2006, Vol. XXI, nº 4, 439-451 XXI, n 4, 439-451 C) 2006, ISPA C 2006, ISPA. Bajšanski University of Rijeka, Croatia University of Rijeka, Kroasia

Lenski, dkk. 2011. Reading and Learning Strategies. Kendal Hunt Publishing Company.

Majid, A. 2007 perencanaan Pembelajaran Bandung: PT. Remaja Rosdakarya

Nurgiyantoro, B. 2012. Penilaian Pembelajaran Bahasa Berbasis Kompetensi. Yogyakarta: BPFE.

Ortlieb, E. 2013. Using Anticipatory Reading Guides to Improve Elementary Students' Comprehension. International Journal of Instruction International Journal of Instruction July 2013 Vol.6, No.2 Juli 2013. Vol.6, No.2 e-ISSN: 1308-1470 e-ISSN: 1308-1470. Monash University, Australia 
Pringgawidagda, S. 2002. Strategi Penguasaaan Berbahasa. Yogyakarta: Adicita Karya Nusa

Putra, N. 2012. Research and Development, Penelitian dan Pengembangan: Suatu Pengantar. Jakarta: RajaGrafindo Persada

Rahim. F. 2007. Pengajaran Membaca di Sekolah Dasar.Jakarta:Bumi Aksara

Redway, K. 1992. Membaca Cepat.(Terjemahan Dandan Riskomar). Jakarta: Pustaka Binaman Pressindo

Rudell, M. R. 2005. Teaching Content Reading and Writing. USA: Wiley

Saddhono, K \& St.Y.Slamet. 2012. Meningkatkan Keterampilan Berbahasa Indonesia (Teori \& Aplikasi). Bandung: Karya Putra Darwati

Sanjaya, W. 2009. Perencanaan dan Desain Sistem Pembelajaran. Jakarta: Prenada Media Group.

Santrock, J. W. 2007. Perkembangan Anak. Terjemahan oleh Mila Rachmawati dan Anna Kuswanti. 2007. Jakarta: Erlangga.

Semiawan, C. R. 2008. Catatan Kecil tentang Penelitian dan Pengembangan Ilmu Pengetabuan. Jakarta: Kencana Prenada Media Group.

Sethna, M. 2011. Literacy Skill and Strategies for Content Area Teachers. Ebook

Setyosari, P. 2010. Metode Penelitian dan Pengembangan. Jakarta:Kencana

Soenarto, 2008. Penelitian Pengembangan Research \& Development (R\&D) Sebagai Upaya Peningkatan Kualitas Pembelajaran. Yogyakarta: UNY.

Somadoyo, S. 2011. Strategi dan Teknik Pembelajaran Membaca. Yogyakarta:Graha Ilmu

Sudjana, H.D. 2010. Metode dan Teknik Pembelajaran Partisipatif. Bandung: Falah Production

Sugiyono. 2009. Metode Penelitian Pendidikan Pendidikan Kuantitatif, Kualitatif, dan R\&D. Bandung: Alfabeta.

Susanto. 2007. Pengembangan KTSP dengan Perspektif Manajemen Visi. Jakarta: Matapena

Tarigan, H. G. 2008. Membaca sebagai Suatu Keterampilan Berbahasa. Bandung: Angkasa.

Taufina. 2015. Keterampilan Berbahasa dan Apresiasi Sastra Indonesia di SD. Padang: Sukabina Press

Thiagarajan, S., Semmel, D.S., \& Melvyn I.S Istructional Develompment for Training Teachers of Exceptional Children: A Sourcebook. Center for Innovation in Teaching the Handicapped. Indiana University Bloomington, Indiana.

Trianto. 2011. Mendesain Model Pembelajaran Inovatif-Progresif. Jakarta: Kencana Prenada Media Group.

Uno, H. B. 2007. Model Pembelajaran Menciptakan Proses Belajar Mengajar yang Kreatif dan Efektif. Jakarta: Bumi Aksara.

Upton, P. 2012. Psikologi Perkembangan. Jakarta: Erlangga

Widodo, C. S. \& Jasmadi. 2008. Panduan Menyusun Bahan Ajar Berbasis Kompetensi. Jakarta: PT Elex Media Kompetindo.

Yuldirim, K. \& A. S. 2012. Silent And Oral Reading Fluency: Which One Is The Best Predictor Of Reading Comprehension Of Turkish Elementary Students. International Journal on New Trends in Education and Their Implications October 2012 Volume: 3 Issue: 4 Article: 07 ISSN 1309-6249. Gazi University Ankara- Turkey

Yusuf, S. LN. 2009. Psikologi Perkembangan Anak dan Remaja. Bandung: Remaja Rosdakarya. 